\title{
DEVELOPMENT OF A NEW METHOD OF PRODUCTION OF PROTEIN VEGETABLE PLANT NANO ADDITIVES USING PAROTHERMOMECHANODESTRUCTION PROCESSES
}

\author{
Viktoriya Pogarskaya \\ viktoria.pogarskaya@ukr.net \\ Raisa Pavlyuk ${ }^{1}$ \\ ktppom@ukr.net \\ Tatyana Kotuyk ${ }^{1}$ \\ micleco555@gmail.com \\ Olga Yurieva ${ }^{1}$ \\ olyaureva@ukr.net \\ Nadiya Maksymova \\ kapochka48@gmail.com \\ in Health Nutrition \\ Kharkov State University of Food Technology and Trade \\ 333 Klochkivska str., Kharkov, Ukraine, 61051
}

${ }^{1}$ Department of Food Technologies of Products from Fruits, Vegetables and Milk and Innovations

\begin{abstract}
The aim of research is to develop a new method for the production of protein plant nanoadditives from dry chickpea in the form of nanopowders and nanopastes using the processes of steam thermo-mechanical destruction, leading to a high degree of mechanical destruction of biopolymers in separate constituent monomers, without destroying the latter. The new method is based on the use as an innovation of a complex effect on raw materials of steam-thermal treatment in modern steam-thermal devices (at a temperature of $+70{ }^{\circ} \mathrm{C}$ ) and non-enzymatic catalysis, which occurs when using fine grinding.

The proposed method makes it possible to more fully reveal the biological potential of plant raw materials and transform hardly soluble, indigestible by the human body components of raw materials (in particular, cellulose, pectin substances, proteins and their nanocomplex and nanoassociates) into components that are easily absorbed by the body.

The method makes it possible to more completely remove from the raw materials inactive bound forms of individual monomers of biopolymers, to reduce the molecular weight of biopolymers. At the same time, the efficiency of the resulting product increases significantly when consumed by the human body.

New additives from chickpea are fundamentally different from traditional ones in properties and physicochemical state. The developed additives act simultaneously five in one: a source of essential amino acids and other biologically active substances, structure formers, gelling agents, thickeners and yellow dyes.

The obtained protein supplements from chickpeas in combination with herbal Nanoadditives (from pumpkin, carrots, lemons, garlic, celery roots, ginger) were used as recipe components in the development of a new generation of confectionery products. The resulting confectionery products differ from the traditional ones in their low sugar and fat content (up to $5 \%$ ), high content of complete protein (from 13 to $20 \%$ ). In addition, $100 \mathrm{~g}$ of new products are able to satisfy the daily requirement for biologically active substances ( $\beta$-carotene, phenolic compounds) and 0.5 daily requirement for vitamin $\mathrm{C}$. The resulting products are natural, do not contain harmful impurities and exceed the quality of world analogues.
\end{abstract}

Keywords: chickpea processing, protein herbal supplements, health products, nanoadditives in powder form, cryopowders, confectionery.

DOI: $10.21303 / 2504-5695.2020 .001543$

\section{Introduction}

Unbalanced nutrition and a deficiency in the diet of protein, vitamins, minerals and other biologically active substances have led to a decrease in the immunity of the population [1-3]. The 
situation is aggravated by the general deterioration of the ecological state, as well as the use in the manufacture of products of a wide range of food additives and synthetic components that negatively affect health and lead to a decrease in immunity $[4,5]$.

A promising type of products that are popular with adults and children are different types of confectionery, especially waffles, cereals, biscuits. The traditional disadvantage of confectionery products is a high content of sugar (from 40 to $65 \%$ ), fat (from 25 to $35 \%$ ), the absence of BAS, and the presence of a significant amount of food additives in the composition.

It is possible to increase the immunity of the human body by using health-improving products with a high content of complete protein and plant biologically active substances (BAS) [4, 6, 7]. Among the BASs that help strengthen the immune system include: antioxidant vitamins (C, E), $\beta$-carotene [5], chlorophyll [7], low molecular weight phenolic compounds and polyphenols [6,8], as well as essential oils, prebiotic substances, etc. [4, 7, 9]. These substances are found in large quantities in fruits and vegetables. Proteins occupy a special place in human nutrition, the role of which in human life is well known $[1,10]$. Proteins cannot be eliminated or replaced with other components, since they perform a variety of functions [11-13].

The main source of complete protein in the manufacture of confectionery products are milk concentrates: skimmed milk powder (SMP), whey powder (WP), nuts (peanuts, walnuts, hazelnuts, hazelnuts, etc.), legumes (soybeans, peas, chickpeas, lentils). However, besides soybeans, other types of legumes have not yet found wide application as a source of protein in the confectionery and food concentrate industries [14-16].

Analysis of literature sources indicates that in international practice, chickpea flour is used to enrich various food products with protein $[17,18]$. It is used to make gluten-free bread and spaghetti, infant formula for babies [18, 19], and functional health-improving meat and vegetable pates [20]. The advantage of using chickpea flour as a source of protein compared to wheat and rice flour in food production is a low glycemic index [17]. In addition, chickpea flour has water and oil content, emulsifying and foaming properties that improve the texture of gluten-free bread and spaghetti [21, 22]. It has been established that chickpea flour is not only a source of vegetable protein with a high content of lysine, leucine, arginine, as well as tannins and phenolic compounds. Chickpea flour exhibits high hydrocoloidal properties when forming the texture of various types of food products with high moisture content [21-23]. For the manufacture of wafer confectionery, breakfast cereals, biscuits, etc., the mass fraction of moisture of which is $1.5 \%$, chickpea flour with a traditional particle size (from 20 to 80 microns) is not used. The use is hindered by the absence in international practice of fundamentally new approaches, ideas, innovations, technological methods that allow obtaining high-quality finely dispersed additives from chickpeas with a high content of soluble biopolymers. The difficulties of using chickpea flour in the manufacture of fillings for wafer confectionery and dry breakfasts are associated with a significant content of hardly soluble components in the flour - biopolymers that do not dissolve in the fatty base of the filling. To increase the solubility of chickpea flour, the authors propose to use the method of deep processing of dried chickpea. The method is based on the complex effect on the raw material of steam-thermal treatment and fine grinding, leading to the mechanical destruction of a significant part of chickpea biopolymers into individual monomers, which are in nanosized form. The use of the proposed method of deep processing made it possible to obtain powders from chickpea with a particle size ten times smaller than that of traditional chickpea flour.

The obtained vegetable protein nanoadditives from chickpea together with additives in nanosized form from fruit and vegetable raw materials were used as recipe components in the development of a new generation of confectionery products. At the same time, additives from plant materials act as a source of protein, BAS fortifiers, structure-formers, and dyes. As recipe components were used: protein supplement from chickpeas, multi-carotene supplement (from carrots, pumpkin), supplements from spicy vegetables (garlic, celery roots and ginger) and fruits (apples, lemons with zest). The use of additives from plant raw materials has made it possible to obtain a new generation of confectionery products that do not contain sugar (or contain an insignificant amount), are characterized by a low fat content, a high content of vegetable protein and essential amino acids. The resulting confectionery products in $100 \mathrm{~g}$ of the product contain a daily requirement for biologically active substances ( $\beta$-carotene, phenolic compounds) and 0.5 daily requirements for ascorbic acid and do not contain any food additives harmful to health. 
The analysis of the literature data indicates that today the question remains unresolved why the use of powdered additives from legumes, in particular chickpeas, as prescription components of confectionery products leads to the production of products containing legume particles, which are felt by the consumer and have low marketable properties. In addition, there remains the issue of reducing the content of sugar and fats in confectionery wafer products due to the use of herbal additives. The method and technology for producing fine protein additives from chickpea have not been developed, and confectionery wafer products with a low sugar and fat content have not been developed.

The aim of the work is to develop a new method for the production of protein plant nanoadditives from chickpeas in the form of nanopowders and nanopastes with a high degree of mechanical destruction of biopolymers in their individual constituent monomers and, on their basis, to obtain confectionery health-improving wafer products. The new method is based on the use as an innovation of a complex effect on chickpeas of steam-thermal treatment in modern steam-thermal devices at a temperature of $70{ }^{\circ} \mathrm{C}$ and non-enzymatic catalysis, which takes place during fine grinding, which makes it possible to obtain additives in nanosized form.

\section{Materials and Methods}

Scientific research was carried out at the Kharkiv State University of Food Technology and Trade (KSUFTT, Ukraine) at the Department of Food Technologies of Products from Fruit, Vegetables and Milk and Innovations in Health Nutrition. Experimental studies were carried out on the basis of the research laboratory "Innovative cryo and nanotechnologies of herbal supplements and health products" of the specified department.

The scientific research presented in the work is a continuation of the work "Creation and implementation of advanced technologies and effective equipment for obtaining new functional food products", which in 2006 was awarded the State Prize of Ukraine in the field of science and technology.

Samples of dried chickpeas of varieties "Slobozhany", "Urozhainy", "Desi" and protein vegetable supplements obtained from them in the form of finely dispersed frozen pastes and powders were selected as raw materials for the development of a new method for the production of protein nanoadditives from dried chickpea. Let's also use finely dispersed vegetable additives (from carrots, pumpkin, apples, lemons with zest, garlic, celery roots and ginger), obtained with the use of additives from chickpeas and herbal supplements, protein natural products (health confectionery, snacks like "Humus", "Falafel”, Soups-puree, etc.) (Fig. 1).

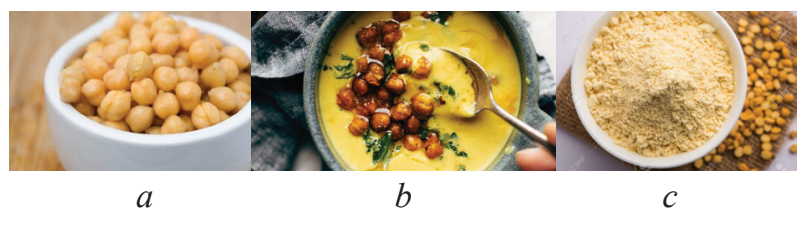

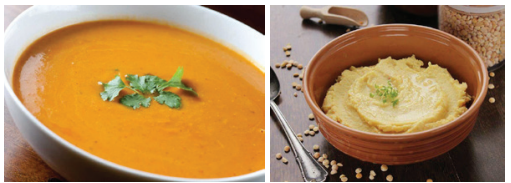

$d$

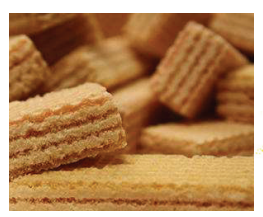

$g$ $e$

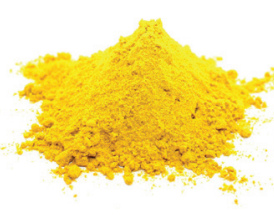

$h$

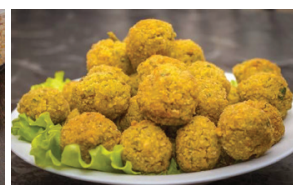

$f$

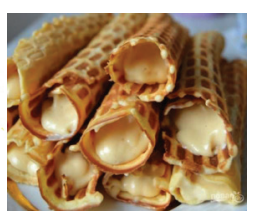

$i$

Fig. 1. Protein natural products using nanoadditives from chickpeas and other natural plant impurities: $a$ - fresh chickpeas; $b$ - puree from chickpeas; $c$ - nanopowder from chickpeas; $d$ - puree soup from chickpeas; $e$ - protein paste "Hummus"; $f$ - falafel; $g$ - waffles with salted filling using chickpeas; $h$ - cereal concentrate; $i$ - wafer rolls stuffed with chickpea 
Steam-thermal processing of dried chickpeas was carried out using modern Italian-made equipment - a UNOX combi oven of the XVC series. For fine grinding, a homogenizer-grinder made in France "Robot Coupe" was used, as well as an innovative food processor "ThermoMix" (France) [6].

The developed vegetable protein supplements and natural protein products obtained with their use to strengthen the immune system are recommended for implementation at large and small food industry enterprises, in restaurant business establishments.

\section{Experiment procedures}

In dried, steam-processed chickpeas, finely dispersed paste and nanopowder from it, the protein content, the content of amino acids in free and bound form, the content of fat, starch, dry matter, pectin, organic acids, and minerals were determined, in particular:

- protein (by the content of total nitrogen in the test samples) - by the Kjeldahl method;

- free and bound amino acids, chromatographic method followed by calculation of the peak area of each amino acid by the method of an external standard;

- starch, by the titrimetric method, which is based on the dissolution of starch in a solution of calcium chloride during heating, precipitation, oxidation with potassium dichromate and subsequent titrimetric determination;

- organic acids, by the titrimetric method, which is based on the neutralization of the acids contained in the product with a $\mathrm{NaOH}$ solution in the presence of phenolphthalein;

- dry substances, by drying the sample to constant weight.

In herbal supplements in the form of cryopowders (from carrots, pumpkin, garlic, celery and ginger roots, apples, lemons with zest), the quality was determined by the content of biologically active substances and prebiotic substances, in particular:

- $\beta$-carotene, by the Mouret colorimetric method after extracting carotene from the product with an organic solvent and purifying carotene from accompanying colored substances using column chromatography;

- L-ascorbic acid, by the method of visual and potentiometric titration with a solution of 2,6-dichlorophenolindophenate $\mathrm{Na}$;

- low molecular weight phenolic compounds (for rutin and chlorogenic acids separately), using the Folin-Denis colorimetric method in terms of rutin and separately for chlorogenic acid;

- polyphenolic compounds (by tannin), by a titrometric method based on the properties of polyphenolic compounds to oxidize in the presence of the indicator indigo carmine, the calculation of tannins was carried out in terms of tannin;

In the initial raw materials, the developed additives from vegetable raw materials and in the obtained protein products with their use, the selection of average samples, the content of dry matter, total sugar and pectin was determined in accordance with the current GOST.

When performing the work, the generally accepted standard and special research methods were used: physicochemical and biochemical. The processing of the results of experimental studies was carried out using the methods of mathematical processing using the computer programs MathCad and Microsoft Excel.

\section{Results}

A new method for the production of protein health-improving plant nanoadditives from dry chickpea in the form of nanopowders and nanopastes with a high degree of parathermal mechanical destruction of biopolymers in their individual constituent monomers without destruction of the latter has been developed. The new method is based on the use of a complex effect on raw materials of steam-thermal processing of raw materials and non-enzymatic catalysis when using fine grinding. The proposed method makes it possible to more fully reveal the biological potential of raw materials and transform sparingly soluble (which are practically not assimilated by the human body) or generally non-pectoral components of raw materials (in particular, cellulose, pectin substances, protein and their nanocomplex and nanoassociates) into low-molecular components that are easily absorbed by the human body. 
It is shown that in the experimental samples of raw materials - dried chickpea, the protein content is $21.56 \%$. The mass fraction of amino acids that are bound in a protein molecule is about $90 \%$, in a free state, respectively, about $10 \%$.

It has been established that the complex application of steam-thermal treatment and fine grinding in the processing of dried chickpea into fine puree and powder leads to the processes of steam-thermal destruction and mechanocracking (destruction) of protein molecules. There is a transformation of the amino acids of the chickpea protein from the bound form into a free easily digestible form. So in the resulting finely dispersed nanopowder and nanoparticle from chickpea, $30 . . .40 \%$ of amino acids remained in a bound state, and $60 . .70 \%$ in free form.

It is known that the size of amino acids ranges from $0.5 \mathrm{~nm}$ to $1.5 \mathrm{~nm}$. That is, for the first time the effect of thermo-mechanical destruction and mechanolysis of chickpea protein molecules was discovered by $60 \ldots 70 \%$ to individual monomers - free amino acids when obtaining finely dispersed puree and nanopowder.

It was also shown that in parallel there is a significant mechanical destruction and transformation of biopolymers of pectin, cellulose and starch into individual monomers (Table 1).

Table 1

The content of biopolymers in the protein plant nanoadditive from chickpea in comparison with the initial raw material and analogue

\begin{tabular}{cccc}
\hline Indicator name & $\begin{array}{c}\text { Dried chickpeas (raw } \\
\text { material) }\end{array}$ & $\begin{array}{c}\text { Protein vegetable supplement with chick- } \\
\text { pea in the form of nanopowder }\end{array}$ & $\begin{array}{c}\text { Chickpea powder } \\
\text { (analog) }\end{array}$ \\
\hline Protein, \% & $21.6 \ldots 25.0$ & $22.1 \ldots 25.5$ & $20.6 \ldots 21.6$ \\
Associated amino acids, \% & $19.4 \ldots 20.0$ & $9.6 \ldots 10.0$ & $16.4 \ldots 17.4$ \\
Free amino acids, \% & $2.1 \ldots .2 .5$ & $12.0 \ldots 12.5$ & $3.6 \ldots 4.2$ \\
Total pectin, \% & $2.7 \ldots 3.5$ & $2.8 \ldots .5$ & $2.9 \ldots 3.3$ \\
Protopectin, \% & $1.9 \ldots . .5$ & $0.5 \ldots 0.8$ & $0.7 \ldots 0.9$ \\
Soluble pectin, \% & $0.8 \ldots 1.0$ & $2.3 \ldots .2 .7$ & $2.2 \ldots 2.4$ \\
Starch, \% & $41.8 \ldots 43.2$ & $25.1 \ldots .26 .1$ & $35.2 \ldots 36.1$ \\
Cellulose, \% & $2.8 \ldots 3.0$ & $1.4 \ldots 1.5$ & $8.2 \ldots 9.0$ \\
Glucose, \% & $2.0 \ldots 2.2$ & $11.5 \ldots 15.4$ & $2.0 \ldots 2.2$ \\
Total sugar, \% & $4.5 \ldots 4.8$ & $17.0 \ldots 17.3$ & $8.2 \ldots 10.0$ \\
Dry matter, \% & $85.7 \ldots 86.2$ & $86.5 \ldots 87.2$ & $84.5 \ldots 85.8$
\end{tabular}

The study of the quality of finely dispersed puree and nanopowders from chickpea showed that biopolymers of protein, pectin and cellulose are $50 . .70 \%$ in an easily soluble form - in the form of monomers of these biopolymers (Table 1).

Additives from chickpea in terms of dispersion and technological characteristics exceed the known analogues.

The obtained results of experimental studies became the basis for the development of a new method for obtaining protein plant nanoadditives from chickpea in the form of finely dispersed puree and nanopowder.

A new method of protein additives from dried chickpeas has been developed from traditional methods of obtaining powders and purees by using the complex action of steam thermal treatment and fine grinding. This makes it possible to obtain protein supplements from heat-treated chickpeas in nanoscale form with a particle size ten times smaller than traditional purees and powders. Rational parameters of a new method of deep processing of chickpea into finely dispersed purees and nanopowders from chickpea have been experimentally determined and scientifically substantiated, technological schemes have been developed, equipment has been selected for both large food production and restaurant business. When obtaining nanopowders, convection or freeze drying of chickpea puree was carried out to a moisture content of no more than $8 \%$. The new technology has been tested in production conditions by «KhPK» Ltd and «Lisova kazka» Ltd.

The obtained protein supplements from chickpeas in combination with herbal nanoadditives (from pumpkin, carrots, lemons with zest, garlic, celery roots, ginger) were used as recipe com- 
ponents in the development of a new generation of confectionery products, cereals, which help to strengthen the immune system. Protein confectionery health-improving products differ from the traditional ones in the absence or insignificant amount of sugar, low fat content (up to $5 \%$ ), high content of complete protein (from 13 to $20 \%$ ). In addition, $100 \mathrm{~g}$ of new products are able to satisfy the daily requirement for biologically active substances ( $\beta$-carotene, phenolic compounds) and 0.5 of the daily requirement for vitamin $\mathrm{C}$. The resulting products are natural, do not contain harmful impurities and are superior in quality to world analogues. New types of confectionery products are unique in their chemical composition, natural products that are recommended for immunoprophylaxis of all segments of the population. The obtained additives are recommended for use as natural protein additives in the manufacture of a wide range of products for a healthy diet (various protein products: snacks such as "Humus", "Falafel", mashed soups, etc.).

Health-improving confectionery products have been tested in production conditions at the enterprises of Kharkov, in particular in «Lisova kazka» Ltd, «KhPK» Ltd, "Combine for baby food" UC, received a positive assessment and are waiting for their consumer and investor.

\section{Conclusions}

A new method for the production of health-improving plant nanoadditives from dried chickpeas with a high degree of mechanodestruction of biopolymers (proteins, cellulose, pectin, starch) (by $60 . .70 \%$ ) in individual monomers in an easily digestible form has been proposed and developed. The new method includes the use as an innovation of the complex effect of the processes of steam thermal treatment on raw materials and fine grinding.

It has been established that the complex application of the processes of steam-thermal treatment and fine grinding in the processing of dried chickpeas into finely dispersed puree and powder leads to mechanocracking of protein molecules and the transformation of amino acids from bound to a free easily digestible form.

It has also been shown that significant mechanical destruction and transformation of biopolymers of pectin, cellulose and starch into individual monomers occurs in parallel. A nanotechnology has been developed for obtaining protein vegetable supplements from chickpeas in the form of finely dispersed puree and nanopowder. The latter differs from the traditional ones by the use of the complex action of steam-thermal treatment and fine grinding of chickpeas into nanosized forms (up to a particle size dozens of times smaller than in traditional purees and powders).

Formulations and technologies of a new generation of confectionery products (wafer confectionery, biscuits, breakfast cereals) have been developed to strengthen the immunity of the population using protein supplements from chickpeas in nanosized form. At the same time, the obtained protein supplements act not only as carriers of high-grade protein in an easily digestible form, but also as substitutes for sugar, fat and play the role of structure and gelling agents for the texture of new types of confectionery. In addition to protein additives from chickpeas, additives from other types of plant raw materials have been introduced into the formulations of new types of confectionery products as prescription components. The additives were used as fortifiers with vitamin phytocomponents, such as: $\beta$-carotene, vitamin $\mathrm{C}$, phenolic compounds, tannins, aromatic substances, and the like. It has been shown that new types of confectionery products are superior in protein content to known analogues, and in terms of $\beta$-carotene content of vitamin $\mathrm{C}$, phenolic compounds have no analogues. There are no harmful food additives in the composition of new confectionery products.

\section{References}

[1] Protein and Amino Acid Requirements in Human Nutrition (2007). Geneva: World Healt Organization, 266. Available at: http://apps.who.int/iris/bitstream/10665/43411/1/WHO_TRS_935_eng.pdf

[2] Global Strategy on Diet, Physical Activity and Health (2010). Expert Consultation. Geneva: World Healt Organization.

[3] Tutel'yan, V. A., Vyalkov, A. I., Razumov, A. N., Mihaylov, V. I., Moskalenko, K. A., Odinets, A. G. et. al. (2010). Nauchnye osnovy zdorovogo pitaniya. Moscow: Izdatel'skiy dom «Panorama», 816.

[4] Kaprel'yants, L. V. (2015). Prebiotiki: himiya, tehnologiya, primenenie. Kyiv: EnterPrint, 252. 
[5] Pavlyuk, R., Pogarska, V., Radchenko, L., Tauber, R. D., Timofeyeva, N. (2016). Deep processing of carotene-containing vegetables and obtaining nanofood with the use of equipment of new generation. Eastern-European Journal of Enterprise Technologies, 4 (11 (82)), 36-43. doi: https://doi.org/10.15587/1729-4061.2016.76232

[6] Pavluk, R., Pogarskiy, A., Kaplun, H., Loseva, S. (2015). Developing the cryogenic freezing technology of chlorophyll-containing vegetables. Eastern-European Journal of Enterprise Technologies, 6 (10 (77)), 42-47. doi: https://doi.org/10.15587/ 1729-4061.2015.56111

[7] Gibson, G. R., Roberfroid, M.(Eds.)(2008). Handbook ofPrebiotics. CRCPress, 504. doi: https://doi.org/10.1201/9780849381829

[8] Sousa, V. M. C. de, Santos, E. F. dos, Sgarbieri, V. C. (2011). The Importance of Prebiotics in Functional Foods and Clinical Practice. Food and Nutrition Sciences, 02 (02), 133-144. doi: https://doi.org/10.4236/fns.2011.22019

[9] Roberfroid, M. B. (2000). Fructo-oligosaccharide malabsorption: benefit for gastrointestinal functions. Current Opinion in Gastroenterology, 16 (2), 173-177. doi: https://doi.org/10.1097/00001574-200003000-00013

[10] Pavlyuk, R., Pogarska, V., Kakadii, I., Pogarskiy, A., Stukonozhenko, T. (2017). Influence of the processes of steam-thermal cryogenic treatment and mechanolysis on biopolymers and biologically active substances in the course of obtaining health promoting nanoproducts. Eastern-European Journal of Enterprise Technologies, 6 (11 (90)), 41-47. doi: https://doi.org/ 10.15587/1729-4061.2017.117654

[11] Herasymenko, S. S., Herasymenko, V. S. (2013). Statystychna kharakterystyka spozhyvannia produktiv kharchuvannia naselenniam Ukrainy. Statystyka Ukrainy, 2, 28-33.

[12] Deineko, L. V., Sheludko, E. I. (2013). Kharchova promyslovist Ukrainy: efektyvnist vykorystannia vyrobnychykh resursiv ta kadrovoho potentsialu. Kyiv: DU «In-t ekon. ta prohnoz. NAN Ukrainy», 120.

[13] Pavlyuk, R., Pogarska, V., Kotuyk, T., Pogarskiy, A., Loseva, S. (2016). The influence of mechanolysis on the activaton of nanocomplexes of heteropolysaccharides and proteins of plant biosystems in developing of nanotechnologies. Eastern-European Journal of Enterprise Technologies, 3 (11 (81)), 33-40. doi: 10.15587/1729-4061.2016.70996

[14] Pavlyuk, R., Pogarskaya, V., Balabai, E., Pogarskiy, A., Stukonozhenko, T. (2019). Development of nanotechnologies for curd desserts and fruit and vegetable cryo-additives for their preparation as bas enrichers, structure-forming agents, and colorants. Eastern-European Journal of Enterprise Technologies, 3 (11 (99)), 13-22. doi: https://doi.org/10.15587/1729-4061.2019.169646

[15] Pavlyuk, R., Pogarskaya, V., Cherevko, O., Pavliuk, V., Radchenko, L., Dudnyk, E. et. al. (2018). Studying the complex of biologically active substances in spicy vegetables and designing the nanotechnologies for cryosupplements and nanoproducts with health benefits. Eastern-European Journal of Enterprise Technologies, 4 (11 (94)), 6-14. doi: https://doi.org/10.15587/ 1729-4061.2018.133819

[16] Dragilev, A. I., Lur'e, I. S. (2001). Tehnologiya konditerskih izdeliy. Moscow: DeLi print, 448.

[17] Belino, P. B., Botangen, E. T., Gonzales, I. C., Gonzales, F. R., Quindara, H. L. (2015). Development of Chickpea (Cicer arietinum L.) Food Products and Its Benefits to Human Nutrition. International Journal of Chemical, Environmental \& Biological Sciences (IJCEBS), 3 (1). Available at: http://www.isaet.org/images/extraimages/P115311.pdf

[18] Malunga, L. N., Bar-El, S. D., Zinal, E., Berkovich, Z., Abbo, S., Reifen, R. (2014). The potential use of chickpeas in development of infant follow-on formula. Nutrition Journal, 13 (1). doi: https://doi.org/10.1186/1475-2891-13-8

[19] Chillo, S., Laverse, J., Falcone, P. M., Del Nobile, M. A. (2008). Quality of spaghetti in base amaranthus wholemeal flour added with quinoa, broad bean and chick pea. Journal of Food Engineering, 84 (1), 101-107. doi: https://doi.org/10.1016/ j.jfoodeng.2007.04.022

[20] Gorlov, I. F., Mikhailovn, T., Sitnikova, O. I., Slozhenkin, M. I., Zlobina, E. Y., Karpenko, E. V. (2016). New Functional Products with Chickpeas: Reception, Functional Properties. American Journal of Food Technology, 11 (6), 273-281. doi: https:// doi.org/10.3923/ajft.2016.273.281

[21] Bird, L. G., Pilkington, C. L., Saputra, A., Serventi, L. (2017). Products of chickpea processing as texture improvers in gluten-free bread. Food Science and Technology International, 23 (8), 690-698. doi: https://doi.org/10.1177/1082013217717802

[22] Mohammed, I., Ahmed, A. R., Senge, B. (2012). Effects of chickpea flour on wheat pasting properties and bread making quality. Journal of Food Science and Technology, 51 (9), 1902-1910. doi: https://doi.org/10.1007/s13197-012-0733-9

[23] Kumar, S., Pandey, G. (2020). Biofortification of pulses and legumes to enhance nutrition. Heliyon, 6 (3), e03682. doi: https:// doi.org/10.1016/j.heliyon.2020.e03682

Received date 11.09.2020

Accepted date 21.10.2020

Published date 30.11.2020
(C) The Author(s) 2020

This is an open access article under the CC BY license (http://creativecommons.org/licenses/by/4.0). 